\title{
Rethinking of Socialist Transformation
}

\author{
Kangjian Shi \\ Shenzhen Institute of Information Technology Kangjian Shi \\ Introduction of author: Kangjian Shi, Male, Born in 1958, Doctoral student, Associate professor. \\ His main research direction: Maoism and the theory of socialism with Chinese characteristics
}

Keywords: Socialist transformation; State capitalism; Public property

\begin{abstract}
Socialist transformation is the beginning of China's socialist society and an important event in the process of China's socialist society. In a lot of things, Chinese favorable economic and social progress and other methods are groping in that period and become pregnant, and many thought were still in the flash to contemporary, such as the mixed ownership reform that we are still in. Most of the time, we do not attempt to discuss its origin, but it does not mean that we will ignore or forget the logical starting point of it.

The socialist transformation has passed about sixty years, the Communist Party of Chinese throughout the course of exploring the socialist road of socialist transformation that is accelerating Chinese into the most important step of socialism, and the socialist revolution with the minimum cost to be successful which has an important influence on Chinese social progress, and brought us many profound thinking.
\end{abstract}

One, when the big social change, our party has always been able to maintain a strategic concentration, and adhere to Marx's materialist conception of history, the situation was calm. From 20 s to 50 s of last century, our party took part in and led the two great social changes, and the two social changes had an important influence on China's social progress. The first social transformation is the transformation of the political system of our party through the application of Marx's theory of class struggle and Lenin's united front thought, combined with China conditions, through the establishment of the alliance of workers and peasants, rural surround City, armed seizure of power; through the establishment of a broad national united front and unite all sectors of society and unite with the national bourgeoisie, the collapse of the big bourgeoisie that against the reactionaries at home and abroad achieved a great victory in the new democratic revolution and founded the people's democratic dictatorship, established the people's Congress system, and it was the real implementation of the labor rights of people in power. The second social change is the change of the economic system. With significant changes in the economic structure of our country during three years of economic recovery, the state-owned economy has been steadily rising in the national economy, socialist ideological has great influence in the hearts of the people of all nationalities, the voice of economic development of rural collective cooperation goes rising, our party thought to timely adjust ideas, and resolutely set off great significance for the Chinese economic system reform with three socialist reform movement in the whole society, especially in the transformation of capitalist industry and commerce, we successfully use the idea of Marx doctrine on redemption of the bourgeoisie, the bourgeoisie and national city instead of against and resist the transformation of the socialist transformation was willing to accept socialism construction that makes suggestions and the dedication of the new socialism. Now, the two times of social change, especially after a social change, is of great significance, and it has established the development direction of future economic in China, explored almost all economic and social development to China and laid the China into socialist material base. Now, if we had entered the enthusiasm and strong desire of socialism for the broad masses of people turn a blind eye to burst out from the heart, hear and listen; if we had to slow down the process of socialism even if it is a small step, let the rural peasant economy in rural power expansion, give free to handicraftsman between city, let bourgeois in city have disorderly competition, it will continue to expand in urban and rural areas where has appeared polarization and the formation of the situation of several class confrontation which formed in the early stage of great liberation political situation would lose, and it would miss the best time of 
China entered the socialist transition period.

Two, the reason of our party has achieved great success in the socialist transformation, in addition to the regime of the advantages of the system, there is a very important factor, in the transformation of the former, the policy is fully prepared. In the war years, on almost every step we have to rely on the guidance of the party's policy, the use of policies to guide and promote all work is a long-standing approach we have consistently adhered to. Comrade Mao Zedong once said, "the policy and strategy are the life of the party, and the leading comrades at all levels must pay full attention to it, there must be no negligent." In order to meet the three major socialist reforms, as early as the founding of the people's Republic, our party has embarked on a series of policy preparations. In June 1950, the Third Plenary Session of the Seventh Central Committee of the Communist Party of China was held in Beijing. Mao Zedong made a written report called The plenary session on the struggle for the basic improvement of the country's financial and economic situation. The meeting pointed out that the fundamental turn for the better in the financial and economic situation would use about three years, and it needed to create three conditions, namely: the completion of land reform; adjusting the existing industry and commerce; government expenditures of thrift. This is actually creating conditions for gradual socialist transformation and planned economic construction. Then, in September 1951, the Central Committee of the party held the first agricultural mutual aid cooperation meeting and formulated the resolution (Draft) on mutual aid and cooperation in agricultural production. The draft pointed out that the productive enthusiasm of Chinese peasants on the basis of land reform concentrated on two kinds of enthusiasm, namely, the enthusiasm of individual economy and the enthusiasm of labor cooperation. The party can not ignore and rudely dampen the enthusiasm of the individual economy of farmers, but we should develop the enthusiasm of farmers' labor assistance in accordance with the principle of voluntariness and mutual benefit. The provisions of this policy reduces the recklessness of work. In December 1953, the central through On the development of agricultural production cooperatives resolution, it is the summary of mutual aid and cooperation experience of guiding farmers to socialist and focus on: the first is the transitional economic organization form of mutual aid group, the second is primary agricultural production cooperatives, and the third is senior agricultural production cooperatives. And it pointed out that these three are different, mutual aid group has a socialist bud, primary agricultural production cooperatives have semi socialist nature, and advanced agricultural production cooperatives have a socialist nature. In the convergence of the three, it should be gradually transferred without impatient. In July 31, 1955, Mao Zedong made a report on The issue of agricultural cooperation at the meeting of the party secretary of the provinces and autonomous regions. Report on the basic experience of the agricultural cooperation movement made a more comprehensive summary with the basic path of agricultural co-operation, the basic principle, basic policy, and the agricultural cooperative relations with mechanization and social reform with the reform of technology that are comprehensively discussed, and it is an important document of the central committee of the Communist Party after the above mentioned two resolution and a guidance of agricultural cooperative. These conference documents and policy combinations play an important guiding role in agricultural cooperation in all parts of the country. After the summer of 1955, there was a climax of agricultural cooperation in China.

The wave of agricultural cooperation has led to the cooperation of handicraft industry. In the winter of 1953, the national handicraft cooperatives held the third national handicraft production cooperation conference. The meeting proposed that the handicraft industry cooperation organization must be based on the level of political consciousness of the needs of production and the manual labor of the masses, take acceptable form by the masses volunteered and organized, adhere to the "active leadership and steady progress" policy. In June 1954, the Central Committee of the Communist Party of China issued the instructions on speeding up the leadership of industrial work in opposition requiring people's governments at all levels to regard the handicraft industry as an important part of local industry. In December of the same year, the Central Committee convened the fourth national conference on handicraft industrial cooperation summing up the experience of hand industry cooperation in the past year and making new arrangements. The requirements of the 
socialist transformation of handicraft industry, and in principle, it should be actively leading and steady progress; in the form of organization, it should be from the handicraft production team, handicraft industry supply and marketing cooperatives handicraft production cooperatives, from small to large, from low to high with gradual development. These policies are very specific, and it covers the content of both macroscopic and microcosmic surface, but it also for the guided, organizers, and simple that fully mobilize the enthusiasm of the two central and local. According to statistics in the first half of 1955, the national handicraft industry (Group) grew to 49800, an increase of 8100 from the end of 1954; the member of society is 1439000 , and there is an increase of 309000 compared with the end of 1954. The trend of cooperation of handicraft industry in China has been formed.

In the socialist transformation of capitalist industry and commerce, we think that the exploration should begin with Yun Chen's first three years of the founding of new China and the development of capitalist industry and commerce in the future. In 1950, Yun Chen proposed a reasonable adjustment commercial process: through the processing of orders, and it is the way of private factories "folder to socialism". This is a superb political strategy to contain the national bourgeoisie. In September 1952, Mao Zedong talked about the problem of how to make the transition to socialism in the secretariat of the central committee meeting, and it also mentioned the public-private partnerships, processing orders in these countries of capitalism that will make the nature of private business change. At this time, a relatively complete policy system has not yet formed a socialist transformation of capitalist industry and commerce center, and it is only a superficial type. In Aprial and May of 1953, the central united front work department organized the state planning commission private enterprise planning department comrades, led by Weihan Li to Wuhan, Nanjing, Shanghai and other private industries concentrated large cities to investigate. During the investigation, the investigation group will pay attention to the specific practice of Lenin's new economic policy and the theory of state capitalism with Chinese combined by convened by the industry and commerce, taxation, in banks and other financial sector and trade union comrades of the forum, listen to the Central Bureau, East China Bureau and the City under the jurisdiction of the relevant person in charge of the report, in-depth study of the development of the change of private capitalism in 3 years since the founding of new China that summed up the development of national capitalism industry experience. Through investigation and research, we have made a clear understanding of various forms of state capitalism, such as its development and its status, role and other major issues. At the end of the investigation, Weihan Li submitted to The central committee the report on the issue of public-private relations in capitalist industry. The report pointed out that when the new China was founded 3 years ago, the private capitalist economy has experienced profound reorganization and transformation, and state capitalism has considerable development, formed from processing, ordering, purchase, purchase and sale, underwriting, and public-private partnerships and a series of from low to high, the position in the national economy after the state-owned economy in modern industry in the second rank. According to the report, the private sector, which accepts processing orders from the state, has developed rapidly in terms of output and technology, and it has formed a close relationship with the state economy. The process of development from lower forms of state capitalism to the advanced form of private industry, which is the gradual transformation of the production relations and the process of gradually moving towards socialism, which is the most advanced form of public-private partnership that will be conducive to the transition to socialism in the form of private enterprises. The report systematically solved the problem of the transformation of private capitalist enterprises to socialism, and it was highly valued by the central committee of the CPC and Mao Zedong. In mid June 1953, the political bureau of the CPC central committee held the two enlarged meeting to discuss Weihan Li's report. The meeting basically agreed with The survey on public-private partnerships in capitalist industry and decided to adopt a state capitalism approach to private businesses. Therefore, the policy of utilizing, limiting and reforming the capitalist industry and commerce that has been formed and unified among the whole party. On this basis, Mao Zedong for the first time gave the general line in the transition period with a complete statement: "from the founding of People's Republic of China 
to the basic completion of socialist transformation, this is a transitional period, the party's general line in the transition period and the general task is to be in ten years to fifteen years or more for some time and basically completed the socialist transformation of agriculture, handicraft industry and capitalist industry and commerce in industrialized countries, and this general line is a beacon understanding of our work which does not depart from this general line, from to the left or right mistakes." Subsequently, in some approval documents of the central committee and the central leading comrades of the report, Mao Zedong made the general route of the content of the expression of a number of changes: (1) change "in ten to fifteen years or longer period of time" to "in a fairly long period of time". (2) change the "industrialization of the country" into "socialist industrialization of the country" . These changes make the content of the general content of the transition period more perfect, and the concept of time is more clear and flexible; in addition, it highlight the nature of industrialization with emphasizing the dominant position of the national socialist industry. The idea of the general line has also become the general basis for the central committee to formulate three major reform policies.

Three, the socialist transformation is one of the greatest social practice in modern history, its significance lies not only in the elimination of private ownership of land breeding soil, destroyed the most stubborn bastion of the national bourgeoisie, solves the problem of ownership, and the more important is the process of socialist road to explore it in the public ownership system that has accumulated valuable experience and lessons.

Empirically, the changes in the old economic relations must be combined with the establishment of a new mode of production. Mao Zedong pointed out: "we are not only doing a social system from private to public ownership of the revolution, but also in technology from handicraft production to mass production and modernization of the revolution, and the two revolutions are together." It is said that the old relations of production revolution, which includes not only the destruction of the old system itself, the elimination of private ownership, also includes the establishment of new production relations, the establishment of public ownership; at the same time to replace the handicraft production with modern production scale. That is to say, the system revolution and production revolution go at the same time, when the old system of the stock of the economy is shrinking, and the representative of new institutional economic incremental expansion marked the success of China's socialist revolution. The same is true. When Chinese socialist transformation was basically completed in 1956, the socialist industry rose from $56 \%$ to $67.5 \%$, and the state capitalist industry increased from $26.9 \%$ to $32.5 \%$. The capitalist industry fell from $17.1 \%$ to near zero. This shift indicates that the socialist transformation and socialist industrialization and the principle of simultaneously greatly mobilized the masses to participate in the construction of the socialist labor enthusiasm, at the same time with the way of industrialization, establish the agricultural industrial production base, strong state, actively promote the socialist economy for the final establishment of the leading position of the public sector of the economy in the national economy construction which has very important significance.

Secondly, when a correct sense or concept has been formed, it should be actively and firmly to guide, grasp, and organize the implementation, rather than passively waiting. After the land reform movement, the Korean War, it can be said that to Chinese communist party's prestige, it is more and more high, and socialist ideology has come. The socialist transformation process a large number of farmers to actively apply for the club, a large number of individual workers to actively join the production cooperatives, and a large number of small and medium-sized capitalists donated donated property that has indicated that the socialist upsurge masses arrived, this time our party is too demanding, but accurate grasp of the key of history moment actively guide and promoted to let the socialism by the slogan into action from the ideal into reality, so that the whole community of people have become followers of the new system, which are very hard to find in the world. This is a great achievement. This is the real embodiment of our party's consistent adherence to historical materialism - to enable the people to fully display their wisdom, to choose the road and to play their role in the course of history.

From the point of lesson, firstly, it has been made in the processing of orders, public-private case, 
private economy has entered into conducive to the development of the socialist economy track, in this case, it should actively promote the state capitalism relatively favorable, explore the economic form of stock or other mixed ownership, and should not be a blindly to the pursuit of scale and socialization degree. Mao Zedong also said that a lot of enthusiasm is better than a positive. In fact we have truth in the edge of the roundabout in Weihan Li's report, it emphasizes the importance of public-private partnerships in the development of economic construction in the paper, if we can pay attention to seriously study, it saw the positive factors of the positive side according to the specific circumstances of Chinese national bourgeoisie, taking into account the positive role where they are in the process of democratic revolution and Chinese national economic recovery period not to destroy the national bourgeoisie as entering the socialist society conditions to stick to, and it does not regard them as a kind of public ownership economy and the threat of force to squeeze down, but puts them as a kind of promote socialist development strength to pull up, lets them as part of an advanced production relations become a positive force for economic development continue to exist for a long time, and makes a small economy playing a big role, there may be bound early breakthrough single ownership from the soviet union's economic model to explore a suitable Chinese economic development path, and the road of Chinese socialism will accelerate the process of the development of productive forces which will be more active.

Secondly, for the economy, socialist transformation process in the adjustment of the structure, it is the political and administrative measure objectively to suppress the economy with "liberal" components, and reduce the people independent space and bound the human ability to work independently. In the process of economic operation, it only focus on the use of fiscal policy to achieve macroeconomic results to measure the evaluation of the economy, while ignoring the positive role of monetary instruments in the entire economic field. Interest rates and exchange rates have been hard for decades in our country. Not to engage in foreign trade and not to study the external market, the human mind completely banned in the domestic solid. Because the capital market is also strictly controlled, or even canceled, blocked the private capital circulation channel for private capital is almost zero, the capital loss with some nature of things, such as profit, speculation and investment, so that the lack of capital combined adhesive effect in the process of production factors, even the commodity economy, distribution according to work, eight grade wage system as a kind of capitalism that is closely related to the unequal "bourgeois rights" to limit the quilt on the market capitalism shackles, lost its economic and social China in proper position and role, the pursuit of ideals and beliefs and povertv to the rich twist were tied together, the China socialism showed weak becoming a mediocre, textbook sense of socialism.

Thirdly, the land system has been solidified. After three transformation, three (right to land ownership and use rights and management rights) are concentrated in the country, the collective land ownership, the use of the hands of decisions by the state, the collective land can not be freely traded. Avoid the old society that as a result of force majeure caused by natural disasters and few farmers mismanagement caused by land annexation the situation, on the surface, the land system tends to be reasonable, and it eliminates the private exploitation risks, eliminate the differences brought by people's ability and quality of land inequality of income, "the labor data into public property". But the actual effect is not ideal, and it is one of the reasons of land rights with the land use rights and management rights over dependent on ownership, it limits the diversity of agricultural production, but also suppress the individual production and management expertise of farmers ideas; then there is no breakthrough in the efficiency in the use of public property on the fear of the land to a private use, to build up the family fortunes of capitalism. "A better socialist grass than a capitalist seedling" is the true portraiture of that time. This is a very profound lesson we should learn.

Conclusion: the socialist transformation occurred in the China victory of the new democratic revolution after a very important historical node, it is related to the Chinese social development direction in the future -- for what's, what road to take, a profound and significant meaning. Although the socialist transformation in Chinese socialism practice process showed excessively quick, such as the previous period of socialist transformation in agriculture is too quickly to recover 
the land from the peasants, commercial property transformed land for administrative accessories, and farmers have no voice in land use. When the small-scale peasant psychology formed in the old economic environment is far from the requirement of "new economic union", the peasants' attachment and responsibility to the land are much lower. Then there are the socialist transformation of capitalist industry and commerce in the process, excessively quickly eliminated the national bourgeoisie, ignoring what exists in the economic and social long-term, necessity and rationality, political standard constraint economy law, so that the most promising high level features in the social development of our country's state capitalism that is not get good use died. This shows that "rights must not go beyond the economic structure of society and the cultural development of society restricted by economic structure." While Chinese successfully completed the socialist transformation of society due to a big step forward, and it successfully entered into socialism which has brought us not only the ideological changes, but the changes of an era.

\section{References}

[1] Selected works of Mao Zedong, Vol. fourth [M], Page 1296

[2] Jingru Zhang, History of People's Republic of China (Volume 1) [M], Qingdao Press, 2009, Page 427

[3] Selected works of Mao Zedong, Vol. sixth [M], People Press, 1999, Page 432

[4] Selected readings of classical works of Marx[M], People Press, 1999, Page 171

[5] Selected readings of classical works of Marx[M], People Press, 1999, Page 175 